\title{
Kesulitan Siswa dalam Membuktikan Masalah Kesamaan dan Ketidaksamaan Matematika Menggunakan Induksi Matematika
}

\author{
I Wayan Puja Astawa ${ }^{*}$, I Gusti Putu Sudiarta ${ }^{2}$, I Nengah Suparta ${ }^{3}$ \\ ${ }^{1,2,3}$ Program Studi Pendidikan Matematika, Universitas Pendidikan Ganesha \\ *puja.astawa@undiksha.ac.id
}

\begin{abstract}
Abstrak
Kesamaan dan ketidaksamaan matematika merupakan pernyataan matematika yang umum berkaitan dengan bilangan yang kebenarannya dapat dibuktikan dengan induksi matematika. Pembuktian dengan induksi matematika melibatkan dua langkah pokok yaitu langkah dasar dan langkah induksi. Kajian tentang induksi matematika berkaitan dengan kesamaan dan ketidaksamaan sangat penting dan kuantitasnya terbatas. Penelitian bertujuan untuk mengetahui apakah ada perbedaan kemampuan siswa dalam membuktikan pernyataan matematika menggunakan induksi matematika dari masalah kesamaan dan ketidaksamaan matematika serta mengidentifikasi miskonsepsi. Penelitian menggunakan metode campuran. Sampel sebanyak 117 orang siswa dari dua sekolah menengah atas di kota Singaraja dipilih dengan teknik kluster random untuk memperoleh data kuantitatif. Sementara itu, subjek penelitian sebanyak dua orang siswa dipilih berdasarkan miskonsepsi yang ditunjukkan saat membuktikan dengan induksi matematika untuk memperoleh data kualitatif. Data kuantitatif kemampuan membuktikan masalah kesamaan dan ketidaksamaan menggunakan induksi matematika dikumpulkan dengan tes tertulis dan data kualitatif terkait miskonsepsi dikumpulkan dengan wawancara. Data kuantitatif dianalisis dengan uji t dua kelompok berpasangan dan uji z untuk proporsi. Sementara itu, data kualitatif dianalisis dengan analisis isi. Hasil penelitian menunjukkan bahwa membuktikan pernyataan dengan induksi matematika terhadap masalah ketidaksamaan lebih sulit dibandingkan membuktikan masalah kesamaan. Kesulitan terjadi baik pada langkah dasar maupun langkah induksi. Miskonsepsi muncul akibat kekeliruan analogi dan intepretasi notasi matematika.
\end{abstract}

Kata kunci: induksi matematika, kesamaan, ketidaksamaan, miskonsepsi

\begin{abstract}
Mathematical similarities and inequalities are common mathematical statements related to numbers whose truth can be proven by mathematical induction. Proving by mathematical induction involves two main steps, namely the basic step and the induction step. The study of mathematical induction related to similarity and inequality is very important and is still relatively limited in quantity. This study aims to determine whether there are significant differences in students' ability to prove mathematical statements using mathematical induction on mathematical similarities and inequalities problems and identify misconceptions. The study was conducted with a mixed method. A sample of 117 students from two high schools in the city of Singaraja was selected by a random cluster technique to obtain quantitative data. Meanwhile, the research subjects were two students selected based on the misconceptions shown to obtain qualitative data. Quantitative data on the ability to prove the similarity and inequality problems using mathematical induction was collected by written tests and qualitative data on misconceptions were collected by interview. Quantitative data were analyzed by a paired group t-test and by $\mathrm{z}$ test for proportions. Meanwhile, qualitative data were analyzed by content analysis of students' works to identify their misconceptions. The results showed that proving the mathematical induction of the inequality problem was more difficult than proving the
\end{abstract}


similarity problem. This difficulty occurs both in the basic step and the induction step. Misconceptions arise due to the fallacy of analogies and interpretations of mathematical notation.

Keywords: equality, inequality, mathematical induction, misconception

Received: December 17, 2019 / Accepted: January 14, 2020 / Published Online: January 31, 2020

\section{Pendahuluan}

Metode pembuktian merupakan cara menunjukkan kebenaran suatu proposisi dalam matematika. Metode pembuktian umumnya menggunakan aturan-aturan logika seperti modus tolen, modus ponen, silogisme dan induksi matematika. Induksi matematika merupakan salah satu metode pembuktian yang banyak digunakan pada matematika diskrit maupun teori bilangan (Harel, 2002; Ashkenazi \& Itzkovitch, 2014). Proses pembuktian dengan induksi matematika melibatkan 2 langkah pokok, yaitu langkah dasar (initial step) dan langkah induksi (base induction step) (Hine, 2017). Kedua langkah ini merupakan inti dari bayangan konsep induksi matematika yang disajikan oleh Lowenthal dan Eisenberg (1992). Pada langkah induksi, pembuktian diawali dengan hipotesis induksi (Andrew, 2007). Pembuktian dengan induksi matematika dapat digambarkan sebagai rangkaian dari modus ponen (Movshovitz-Hadar, 1993).

Metode pembuktian dengan induksi matematika dikenalkan sejak awal pada siswa sekolah menengah atas kelas XI semester 1 program MIPA berdasarkan kurikulum 2013 yang saat ini berlaku. Materi induksi matematika pada kuriukulum 2013 secara tegas dinyatakan dalam Permendikbud nomor 24 tahun 2016 tentang kompetensi inti (KI) dan kompetensi dasar (KD) pada Lampiran 16. Pada aspek pengetahuan, KD yang diharapkan adalah menjelaskan metode pembuktian pernyataan matematis berupa barisan, ketidaksamaan, keterbagian dengan induksi matematika. Sementara itu, pada aspek keterampilan, KD yang diharapkan adalah menggunakan metode pembuktian induksi matematika untuk menguji pernyataan matematis berupa barisan, ketidaksamaan, keterbagian. Hal ini sejalan dengan pernyataan Ashkenazi dan Itzkovitch (2014) yang menyebutkan bahwa induksi matematika yang dipelajari siswa di sekolah menengah masih sangat terbatas. Proses pembuktian dengan induksi matematika baik pada proposisi yang melibatkan relasi kesamaan maupun relasi ketidaksamaan melibatkan 2 langkah pokok, yaitu langkah dasar dan langkah induksi.

Hasil belajar siswa pada materi induksi matematika diharapkan memenuhi kriteria ketuntasan belajar minimal (KKM) yang diharapkan. Akan tetapi, hasil belajar siswa pada 
materi ini masih jauh dari harapan. Hasil wawancara dengan guru SMA Negeri 1 Singaraja tahun 2018 yang lalu menunjukkan bahwa KKM siswa pada materi induksi matematika adalah 75, akan tetapi lebih dari 50\% siswa memperoleh hasil belajar di bawah KKM yang ditetapkan. Sementara wawancara dengan beberapa siswa di sekolah yang sama memperoleh hasil bahwa mereka sangat susah memahami induksi matematika.

Beberapa peneliti telah melakukan penelitian tentang induksi matematika. Gruver (2010) mengkaji perkembangan konsep-konsep siswa dalam induksi matematika dan menyimpulkan bahwa orientasi investigasi mempengaruhi jenis pengetahuan yang dikonstruksi dan perbedaan orientasi investigasi muncul akibat perbedaan kebutuhan personal. Öhman (2016) menyajikan contoh-contoh pembuktian dengan induksi matematika dan menyatakan pembuktian dengan induksi matematika memiliki nulai estetika yang tinggi.

Kesulitan atau kelemahan siswa dalam membuktikan pernyataan matematika dengan induksi matematika telah dikaji oleh beberapa peneliti. Avital dan Libeskind (1978) mengelompokkan 3 kategori masalah siswa dalam membuktikan dengan induksi matematika yaitu masalah teknis, masalah matematis, dan masalah konseptual. Masalah teknis berkaitan ketidakmampuan siswa melakukan langkah-langkah yang diperlukan untuk membangun bukti. Masalah matematis berkenaan dengan kekeliruan interpretasi dalam penerapan prinsip induksi matematika. Masalah konseptual berkaitan dengan ketidakpahaman perbedaan penalaran induktif dan deduktif, keyakinan bahwa langkah dasar bukan merupakan langah yang esensial dan sering dilupakan dalam keseluruhan pembuktian. Sejalan dengan Avital dan Libeskind, Kong (2003) juga mengungkapkan 3 kesulitan siswa dalam membuktikan pernyataan induksi matematika. Kesulitan siswa dalam membuktikan dengan induksi berkaitan dengan konsep, prosedur dan teknik dari induksi matematika.

Ernest (1984) mengkaji kesulitan siswa dalam masalah induksi matematika pada keterampilan perilaku dan pemahaman konsep. Keterampilan perilaku yang diamati meliputi kemampuan membuktikan basis induksi, kemampuan membuktikan langkah induksi, dan kemampuan menunjukkan bukti induksi yang benar. Pemahaman konsep meliputi mendefinisikan sifat bilangan bulat dan fungsi serta pengulangan dan urutan bilanganbilangan bulat. Baker (1996) mengkaji siswa-siswa yang mulai belajar induksi matematika pada siswa sekolah menengah dan college dan menyimpulkan bahwa siswa lebih sering fokus pada aspek prosedur dibandingkan aspek konsep. Lebih lanjut dia menyimpulkan kesulitankesulitan dalam induksi matematika dipengaruhi oleh pengetahuan konten matematika spesifik seperti notasi sigma, notasi faktorial, definisi variabel dan aljabar.

Kesulitan dalam pembuktian dengan induksi matematika yang berkaitan dengan konsep 
dan prosedur juga dikaji oleh Ashkenazi dan Itzkovitch (2014). Mereka menyatakan bahwa ada tiga masalah utama siswa dalam membuktikan dengan induksi matematika, yaitu ketidakpahaman terhadap bukti deduktif, ketidaklengkapan pemahaman terhadap makna basis induksi, dan ketidakpahaman terhadap peningkatan. Sementara itu, kesulitan khusus dalam penggunaan prosedur dan logika dalam pembuktian dengan induksi matematika dikaji oleh Segal (1998). Dia menyatakan bahwa kesulitan siswa dalam membuktikan dengan induksi matematika adalah ketidakmampuan dalam menggunakan implikasi dalam induksi.

Pada tulisan ini dikaji perbedaan kemampuan siswa dalam membuktikan pernyataan matematika dengan induksi matematika berkaitan dengan masalah kesamaan dan ketidaksamaan pada materi bilangan. Rumusan masalah yang dikaji adalah apakah ada perbedaan kemampuan membuktikan dengan induksi matematika antara masalah kesamaan dan ketidaksamaan matematika pada siswa SMA di kota Singaraja secara umum maupun secara khusus pada setiap langkah induksi matematika dan mengidentifikasi miskonsepsi yang dilakukan oleh siswa dalam membuktikan masalah kesamaan dan ketidaksamaan matematika dengan induksi matematika.

\section{Metode}

Penelitian dilakukan dengan mengambil sampel dengan teknik cluster dan proporsional sampling sehingga diperoleh 117 siswa yang berasal dari dua SMA Negeri di kota Singaraja yaitu SMA Negeri 1 Singaraja yang berlokasi di pusat kota Singaraja dan SMA Negeri 3 Singaraja yang berlokasi di pinggiran kota Singaraja. Sebanyak 59 orang siswa SMA Negeri 1 Singaraja dan 58 orang siswa SMA Negeri 3 Singaraja terpilih sebagai sampel yang masingmasing berasal dari 2 kelas XI berbeda. Setiap siswa diberikan tes yang terdiri dari 4 masalah pembuktian matematika dengan induksi matematika berkaitan dengan bilangan bulat. Keempat masalah tersebut adalah sebagai berikut.

Masalah 1. Buktikan bahwa $1+3+5+\ldots+(2 n-1)=n^{2}$ untuk setiap bilangan $n \geq 1$

Masalah 2. Buktikan bahwa $\left(1-\frac{1}{4}\right)\left(1-\frac{1}{9}\right)\left(1-\frac{1}{16}\right) \ldots\left(1-\frac{1}{n^{2}}\right)=\frac{n+1}{2 n}$

Masalah 3. Buktikan bahwa $1+2+3+\ldots+n>\frac{n}{2}$ untuk setiap bilangan asli

Masalah 4. Buktikan bahwa $n^{2} \leq 2^{n}$ untuk $n \geq 4$.

Masalah 1 berkaitan dengan pembuktian menggunakan induksi matematika pada masalah persamaan dengan kebenaran awal $\mathrm{n}=1$. Masalah 2 berkaitan dengan pembuktian menggunakan induksi matematika pada masalah persamaan dengan kebenaran awal $\mathrm{n} \neq 1$. 
Masalah 3 berkaitan dengan pembuktian menggunakan induksi matematika pada masalah ketidaksamaan dengan kebenaran awal $n=1$. Masalah 4 berkaitan dengan pembuktian menggunakan induksi matematika pada masalah ketidaksamaan dengan kebenaran awal $\mathrm{n} \neq 1$.

Data penelitian dianalisis secara kuantitatif dan kualitatif. Analisis data secara kuantitatif dilakukan dengan uji t untuk dua kelompok berpasangan dan uji z untuk proporsi. Uji t untuk dua kelompok berpasangan menggunakan formula berikut.

$t=\frac{M_{d}}{\sqrt{\frac{\sum x_{d}^{2}}{n(n-1)}}}$ (Supardi, 2016),

dengan

$M_{d}=$ rerata gain skor kemampuan membuktikan dengan induksi matematika antara masalah kesamaan dan ketidaksamaan.

$x_{d}^{2}=$ kuadrat deviasi skor gain kemampuan membuktikan dengan induksi matematika antara masalah kesamaan dan ketidaksamaan.

$n$ = banyak sampel.

Sementara itu, uji z untuk proporsi adalah sebagai berikut.

$z_{\text {hitung }}=\frac{p_{1}-p_{2}}{\text { s.e }\left(p_{1}-p_{2}\right)}$ dengan s.e $\left(p_{1}-p_{2}\right)=\sqrt{p(1-p)\left(\frac{1}{n_{1}}+\frac{1}{n_{2}}\right)}$ dan $p=\frac{n_{1} p_{1}+n_{2} p_{2}}{n_{1}+n_{2}}$

dengan

$p_{1}=$ proporsi siswa salah membuktikan masalah induksi berkaitan dengan pembuktian menggunakan induksi matematika terhadap masalah persamaan.

$p_{2}=$ proporsi siswa salah membuktikan masalah induksi berkaitan dengan pembuktian menggunakan induksi matematika terhadap masalah pertidaksamaan.

$n_{1}=$ banyak siswa yang menjawab masalah induksi berkaitan dengan pembuktian menggunakan induksi matematika terhadap masalah persamaan.

$n_{2}=$ banyak siswa yang menjawab masalah induksi berkaitan dengan pembuktian menggunakan induksi matematika terhadap masalah pertidaksamaan.

Analisis data secara kualitatif dilakukan dengan analisis isi terhadap pembuktian yang dilakukan oleh siswa untuk memperoleh kesulitan-kesulitan siswa dalam membuktikan pernyataan matematika dengan induksi matematika. Analisis kualitatif merujuk pada prosedur dari Strauss \& Corbin (1990) dalam merunut hasil pembuktian siswa dan melengkapinya dengan wawancara untuk mengidentifikasi faktor-faktor penyebab miskonsepsi siswa dalam membuktikan dengan induksi matematika. Data yang dianalisis secara kualitatif adalah data 
dari 2 orang siswa yang menunjukkan miskonsepsi dalam langkah-langkah pembuktian dengan induksi matematika untuk masalah 1 dan masalah 2.

\section{Hasil Penelitian}

Hipotesis yang diuji dalam penelitian ini adalah hipotesis yang berkaitan dengan perbedaan kemampuan siswa membuktikan masalah kesamaan dan ketidaksamaan matematika dengan induksi matematika dan hipotesis yang berkaitan dengan perbedaan kemampuan membuktikan masalah kesamaan dan ketidaksamaan matematika dengan induksi matematika pada setiap langkah induksi matematika, yaitu langkah dasar dan langkah induksi. Kemampuan membuktikan masalah kesamaan dan ketidaksamaan matematika dengan induksi matematika dari 117 siswa sekolah menengah atas di kota Singaraja disajikan pada Tabel 1.

Tabel 1. Kemampuan membuktikan dan proporsi siswa menjawab salah

\begin{tabular}{ccc}
\hline Masalah & Rata-rata & Banyak siswa menjawab tidak sepenuhnya benar \\
\hline 1 & $5,69(\mathrm{SE}=0,09)$ & $14(11,97 \%)$ \\
2 & $2,62(\mathrm{SE}=0,26)$ & $70(59,83 \%)$ \\
3 & $4,66(\mathrm{SE}=0,17)$ & $42(35,90 \%)$ \\
4 & $2,13(\mathrm{SE}=0,17)$ & $100(85,47 \%)$ \\
\hline
\end{tabular}

$\mathrm{SE}=$ standar error

Dari Tabel 1 terlihat bahwa rata-rata tertinggi kemampuan siswa membuktikan dengan induksi matematika adalah membuktikan masalah kesamaan matematika dengan kebenaran awal $\mathrm{n}=1$ (masalah 1) sementara rata-rata terendahnya adalah membuktikan masalah ketidaksamaan matematika dengan kebenaran awal $n \neq 1$ (masalah 4). Sementara itu, dua proporsi tertinggi siswa tidak sepenuhnya benar dalam membuktikan dengan induksi matematika berturut-turut adalah membuktikan masalah ketidaksamaan (masalah 4) dan masalah kesamaan (masalah 2) yang keduanya berkaitan dengan kebenaran awal $n \neq 1$.

Ringkasan pengujian hipotesis tentang ada perbedaan kemampuan membuktikan dengan induksi matematika antara masalah kesamaan dan ketidaksamaan matematika pada siswa SMA di kota Singaraja disajikan pada Tabel 2.

Tabel 2. Ringkasan uji perbedaan skor masalah kesamaan dan ketidaksamaan matematika

\begin{tabular}{llllll}
\hline Perbedaan skor & Rata-rata & Standard error & t & Nilai p & Keterangan \\
\hline Masalah 1 dan Masalah 3 & 1,03 & 0,17 & 6,18 & $<0,01$ & Signifikan \\
Masalah 2 dan Masalah 4 & 0,49 & 0,19 & 2,47 & $<0,01$ & Signifikan \\
\hline
\end{tabular}

Selanjutnya, untuk menguji hipotesis tentang perbedaan kemampuan siswa dalam membuktikan masalah kesamaan dan ketidaksamaan matematika pada setiap langkah induksi matematika maka dihitung proporsi siswa yang salah membuktikan langkah dasar dan 
langkah induksi pada pembuktian dengan induksi matematika. Proporsi siswa yang salah membuktikan langkah-langkah induksi pada keempat masalah di atas disajikan pada Tabel 3.

Tabel 3. Proporsi siswa salah membuktikan langkah induksi matematika

\begin{tabular}{clccc}
\hline Masalah & Langkah induksi matematika & Banyak siswa & Total Siswa & Proporsi \\
\hline \multirow{2}{*}{2} & Langkah dasar & 1 & 117 & 0,0086 \\
& Langkah induksi & 14 & 117 & 0,1197 \\
& Langkah dasar & 62 & 117 & 0,5299 \\
& Langkah induksi & 70 & 117 & 0,5983 \\
& Langkah dasar & 1 & 117 & 0,0086 \\
& Langkah induksi & 41 & 117 & 0,3504 \\
& Langkah dasar & 95 & 117 & 0,8120 \\
& Langkah induksi & 100 & 117 & 0,8547 \\
\hline
\end{tabular}

Ringkasan hasil pengujian hipotesis tentang ada perbedaan kemampuan membuktikan dengan induksi matematika antara masalah kesamaan dan ketidaksamaan pada siswa SMA di kota Singaraja pada setiap langkah induksi matematika disajikan pada Tabel 4.

Tabel 4. Ringkasan uji proporsi kesalahan membuktikan dengan induksi matematika

\begin{tabular}{llllll}
\hline $\begin{array}{l}\text { Perbedaan proporsi } \\
\text { kesalahan membuktikan } \\
\text { pada langkah induksi } \\
\text { matematika }\end{array}$ & $p_{1}-p_{2}$ & $\mathbf{s . e}\left(p_{1}-p_{2}\right)$ & $\mathbf{z}$ & Nilai p & Keterangan \\
\hline $\begin{array}{l}\text { Langkah dasar } \\
\text { Masalah 1 dan Masalah 3 }\end{array}$ & 0,0000 & 0,0121 & 0,0000 & $>0,01$ & Tidak signifikan \\
Masalah 2 dan Masalah 4 & 0,2307 & 0,0554 & 4,1613 & $<0,01$ & Signifikan \\
Langkah induksi & & & & & \\
Masalah 1 dan Masalah 3 & 0,2821 & 0,0614 & 4,5920 & $<0,01$ & Signifikan \\
Masalah 2 dan Masalah 4 & 0,2564 & 0,0583 & 4,3995 & $<0,01$ & Signifikan \\
\hline
\end{tabular}

\section{Pembahasan}

Hasil pengujian pada Tabel 1 menunjukkan bahwa terdapat perbedaan yang signifikan kemampuan siswa membuktikan dengan induksi matematika antara masalah kesamaan dan ketidaksamaan matematika baik menggunakan kebenaran awal $\mathrm{n}=1$ maupun $\mathrm{n} \neq 1$. Selanjutnya dari hasil pengujian pada Tabel 2 diperoleh bahwa proporsi siswa yang membuat kesalahan dalam membuktikan masalah kesamaan dengan induksi matematika lebih sedikit dibandingkan siswa yang membuat kesalahan dalam membuktikan masalah ketidaksamaan. Kedua hal ini menunjukkan bahwa siswa lebih mudah membuktikan masalah kesamaan dengan induksi matematika dibandingkan dengan membuktikan masalah ketidaksamaan. Hal ini konsisten untuk pernyataan matematika yang kebenaran awalnya mulai dari 1 maupun bukan mulai dari 1 . 
Perbedaan kemampuan membuktikan pernyataan matematika dengan menggunakan induksi matematika terjadi juga pada setiap langkah induksi matematika. Hal ini terlihat dari banyak siswa yang mengalami kesalahan membuktikan pada langkah dasar induksi matematika maupun langkah induksi matematika pada Tabel 3 dan Tabel 4. Pada langkah dasar pembuktian induksi matematika menggunakan masalah kesamaan dan ketidaksamaan yang kebenaran awalnya mulai dari 1 terlihat bahwa tidak terdapat perbedaan yang signifikan. Akan tetapi, pada langkah induksi, terdapat perbedaan banyak siswa yang mengalami kesulitan secara signifikan. Sementara itu, pada masalah yang kebenaran awalnya tidak sama dengan 1, banyak siswa yang mengalami kesulitan pada pembuktian langkah dasar dan langkah induksi berbeda secara signifikan. Jika dilihat dari proporsi siswa yang mengalami kesulitan dalam membuktikan dengan induksi matematika dapat disimpulkan bahwa siswa lebih banyak mengalami kesulitan dalam membuktikan dengan induksi matematika dari masalah ketidaksamaan yang kebenaran awalnya bukan bernilai 1 .

Salah satu temuan menarik dari analisis terhadap pekerjaan siswa membuktikan dengan induksi matematika adalah miskonsepi. Miskonsepsi dialami siswa pada saat menunjukkan kebenaran awal dari suatu pernyataan matematika khususnya pernyataan yang kebenaran awalnya bukan $\mathrm{n}=1$. Miskonsepsi dalam hal ini berkaitan dengan kesalahan menginterpretasi kebenaran langkah dasar. Siswa S1 merupakan salah satu siswa yang menunjukkan miskonsepsi dalam membuktikan pernyataan matematika dengan induksi pada langkah dasar. Siswa S1 menunjukkan kebenaran awal pernyataan masalah 2 dengan menyatakan kebenarannya untuk $n=1$ padahal untuk $n=1$ pernyataan tersebut tidak bermakna. Hasil pekerjaan S1 ditunjukan pada Gambar 1.

$$
\begin{aligned}
& \text { a. Untuk } n=1 \\
&\left(1-\frac{1}{n^{2}}\right)=\frac{n+1}{2 n} \\
&\left(1-\frac{1}{1^{2}}\right)=\frac{1+1}{2 \cdot 1} \\
&\left(1-\frac{1}{1}\right)=\frac{2}{2} \\
& 0=1 \\
& \text { b. Un+uk } n=k \\
&\left(1-\frac{1}{4}\right)\left(1-\frac{1}{9}\right)\left(1-\frac{1}{16}\right) \cdots\left(1-\frac{1}{n^{2}}\right)=\frac{k+1}{2 k} \\
& \text { C. untuk } n=k+1 \\
&\left(1-\frac{1}{4}\right)\left(1-\frac{1}{9}\right)\left(1-\frac{1}{16}\right) \cdots\left(1-\frac{1}{(k+1)^{2}}\right)=\frac{(k+1)+1}{2(k+1)}
\end{aligned}
$$

Gambar 1. Hasil Pekerjaan S1 
Hasil wawancara dengan S1 disajikan pada transkrip berikut. Hasil ini dapat mengungkap miskonsepsi yang muncul pada siswa bersangkutan.

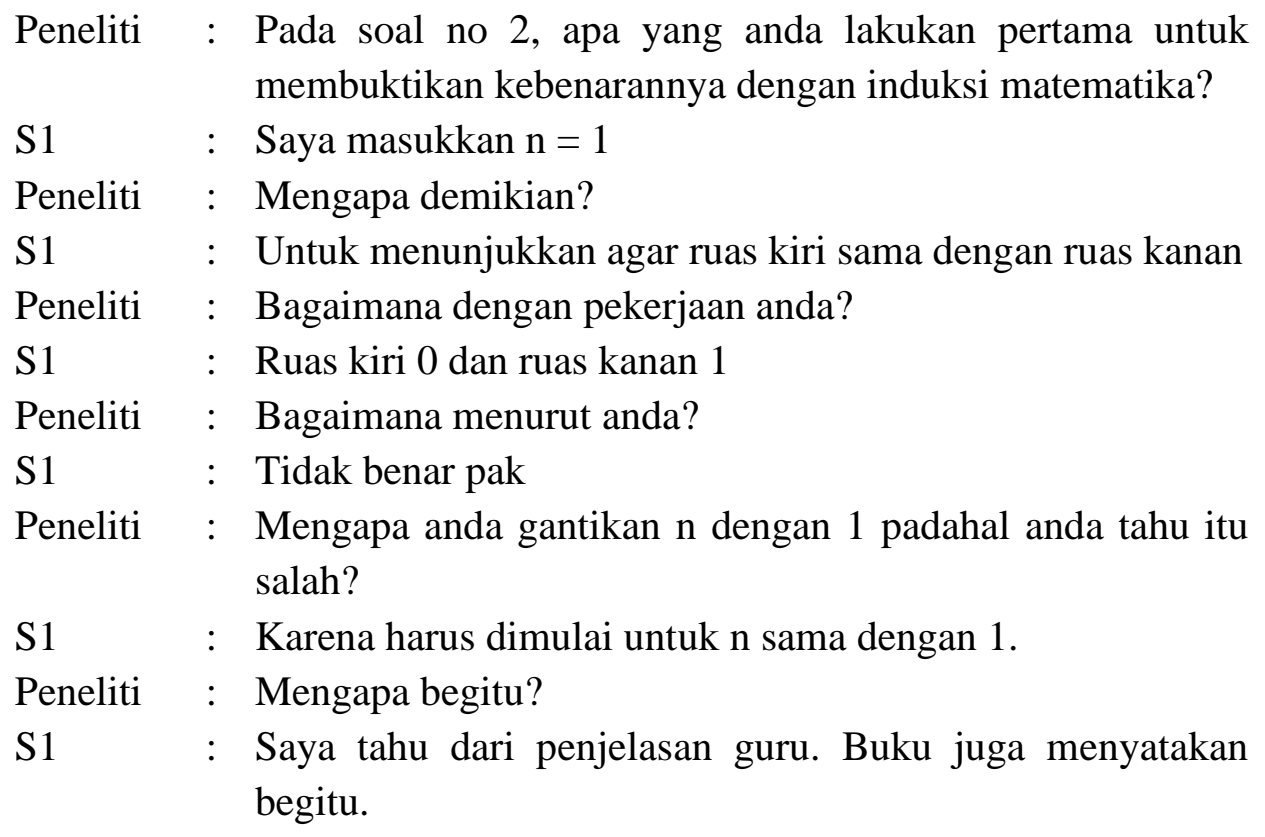

Hasil yang sama diperoleh saat S1 mengerjakan masalah 4 yang juga merupakan masalah yang kebenaran awalnya tidak sama dengan 1. Hasil wawancara ini menunjukkan bahwa siswa S1 memiliki konsep yang salah atau miskonsepsi terhadap pernyataan awal (langkah dasar) yang harus dibuktikan. Siswa ini menganggap bahwa membuktikan pernyataan dasar induksi harus dimulai dari $n=1$. Miskonsepsi siswa ini bersumber dari kesalahan analogi yaitu kesalahan menginterpretasi dan meniru contoh pembuktian dari sumber yang dipelajari.

Disamping miskonsepsi terhadap langkah dasar, hasil analisis juga menemukan miskonsepsi pada langkah induksi. Siswa S2 merupakan salah satu siswa yang menunjukkan miskonsepsi dalam membuktikan pernyataan matematika dengan induksi matematika pada langkah induksi. Hal ini terlihat dari pekerjaan siswa S2 untuk masalah 2 berikut.

$$
\begin{aligned}
n & =2 \\
& =\left(1-\frac{1}{4}\right)\left(1-\frac{1}{9}\right)\left(1-\frac{1}{16}\right)\left(1-\frac{1}{n^{2}}\right)=\frac{n+1}{2 n} \\
& =\left(1-\frac{1}{2^{2}}\right)=\frac{2+1}{2(2)}=\left(1-\frac{1}{4}=\frac{3}{4}=\frac{3}{4}=\frac{3}{4}=\frac{3}{4},\right. \\
n & =k \\
& \left(1-\frac{1}{k^{2}}\right)=\frac{k+1}{2(k)}
\end{aligned}
$$

Gambar 2. Hasil Pekerjaan S2 
Hasil wawancara dengan S2 disajikan pada transkrip berikut. Hasil ini dapat mengungkap miskonsepsi yang muncul pada siswa bersangkutan.

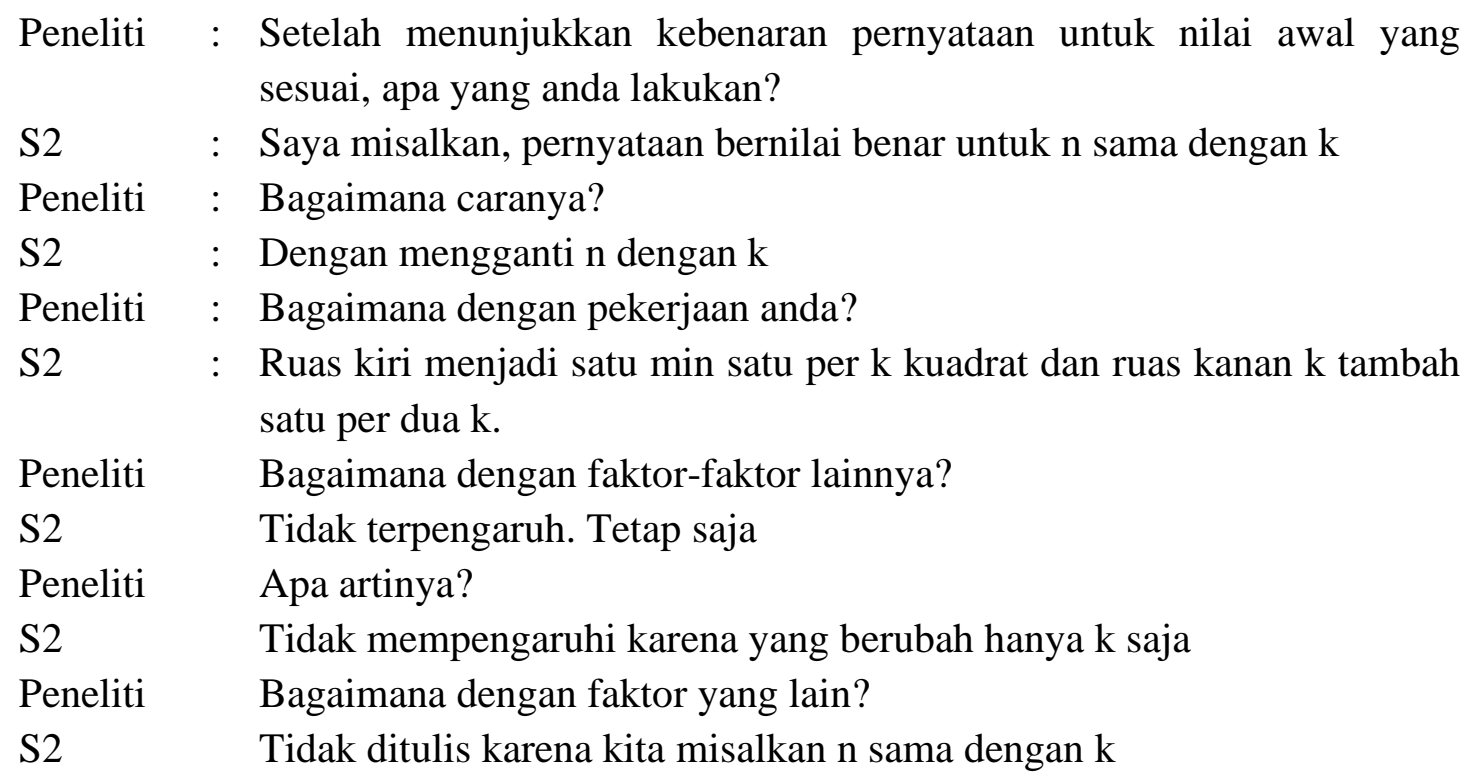

Hasil wawancara ini menunjukkan bahwa siswa salah memahami asumsi $n$ sama dengan $k$. Siswa S2 mengasumsikan saat $n=k$, faktor atau suku yang memuat $n$ digantikan dengan $k$ tanpa memperhatikan faktor atau suku lainnya yang tekait dengan $n$ tersebut. Miskonsepsi ini berkaitan dengan kesalahan menginterpretasi notasi matematika yaitu tidak memahami makna perbedaan simbol secara keseluruhan dimana setiap simbol mengandung suatu makna dalam konteks kesatuan formula. Simbol yang berbeda mempunyai makna yang berbeda pada satu kesatuan formula. Adanya miskonsepsi dalam membuktikan dengan induksi matematika telah diungkapkan oleh temuan-temuan Avital \& Libeskind (1978), Ernest (1984), Kong (2003), dan Dogan (2016). Mereka menyatakan bahwa miskonsepsi merupakan salah satu kesalahan yang dibuat oleh siswa saat membuktikan pernyataan matematika dengan induksi matematika.

\section{Simpulan}

Kemampuan siswa membuktikan masalah ketidaksamaan matematika dengan induksi matematika lebih rendah dibandingkan membuktikan masalah kesamaan. Siswa lebih sulit membuktikan masalah ketidaksamaan dengan induksi matematika dibandingkan masalah kesamaan baik pada langkah dasar maupun langkah induksi. Terdapat miskonsepsi dalam membuktikan pernyataan matematika dengan induksi matematika baik pada langkah dasar maupun langkah induksi. Miskonsepsi siswa dalam membuktikan dengan induksi matematika bersumber dari kekeliruan analogi atau kekeliruan menginterpretasi notasi matematika. 


\section{Referensi}

Andrew, L. (2007). Reasons why students have difficulties with mathematical induction. Retrieved from files.eric.ed.gove/fulltext/ED495959.pdf.

Ashkenazi, Y., \& Itzkovitch, E. (2014). Proof by mathematical induction. International Journal of Innovation and Research in Educational Sciences, 1(3), 186-190.

Avital, S., \& Libeskind, S. (1978). Mathematical induction in the classroom: Didactical and mathematical issues. Educational Studies in Mathematics, 9(4), 429-438. https://doi.org/10.1007/BF00410588.

Baker, J. (1996). Student's difficulties with proof by mathematical induction. Paper Presented at Annual Meeting of the American Educational Research Association. New York.

Dogan, H. (2016). Mathematical induction: deductive logic perspective. European Journal of Science and Mathematics Education, 4(3), 315-330.

Ernest, P. (1984). Mathematical induction: A pedagogical discussion. Educational Studies in Mathematics, 15(2), 173-189. https://doi.org/10.1007/BF00305895.

Gruver, J. D. (2010). Growth in students' conceptions of mathematical induction. Retrieved from All Theses and Dissertations. 2166 website: https://scholarsarchive.byu.edu/etd/2166.

Harel, G. (2002). The development of mathematical induction as a proof scheme: a model for DNR-Based Instruction. In S. R. Campbell \& R. Zaskis (Eds.), Learning and Teaching Number Theory: Research in Cognition and Instruction (pp. 185-212). New Jersey: Ablex Publishing Corporation.

Hine, G. (2017). Proof by mathematical induction: Professional practice for secondary teachers. In V. Barker, T. Spencer, \& K. Manuel (Eds.), Capital Maths. Proceedings of the 26th Biennial Conference of the Australian Association of Mathematics Teachers (pp. 117-124). Retrieved from https://www.aamt.edu.au/Library/Conferenceproceedings.

Kong, C. M. (2003). Mastery of mathematical induction among junior college. The Mathematics Educator, 7(2), 37-54.

Lowenthal, F., \& Eisenberg, T. (1992). Mathematical induction in school: an illusion of rigor? School Science and Mathematics, 92(5), 233-238. https://doi.org/10.1111/j.19498594.1992.tb15580.x.

Movshovitz-Hadar, N. (1993). Mathematical induction: a focus on the conceptual framework. School Science and Mathematics, 93(8), 408-417. https://doi.org/10.1111/j.19498594.1993.tb12271.x.

Öhman, L.-D. (2016). A beautiful proof by induction. Journal of Humanistic Mathematics, 6(1), 73-85. https://doi.org/10.5642/jhummath.201601.06.

Permendikbud nomor 24 tahun 2016 tentang Kompetensi Inti dan Kompetensi Dasar Pelajaran pada Kurikulum 2013 pada Pendidikan Dasar dan Pendidikan Menengah. (2016). Jakarta: Kemdikbud.

Segal, J. (1998). Learners' difficulties with induction proofs. International Journal of Mathematical Education in Science and Technology, 29(2), 159-177. https://doi.org/10.1080/0020739980290201.

Strauss, A., \& Corbin, J. (1990). Basics of qualitative research: Grounded theory procedures and techniques. Thousand Oaks, CA: Sage Publications, Inc.

Supardi. (2016). Aplikasi statistik dalam penelitian konsep statistik yang lebih komprehensip. Jakarta: Change Publication. 